\title{
Do Diversities on Board Affect to Dividend Payout Ratio in Indonesia?
}

\author{
Annisa Paramaswary Aslam \\ \{parawansaannisa@gmail.com\} \\ Department of Management, State University of Makassar, Makassar, Indonesia
}

\begin{abstract}
This study purpose to explore gender diversity of listed manufacturing firms from 2014-2016 in Indonesia. Secondly, to know the effect of board gender diversity on the dividend payments. Last, to investigate the effect of the moderating variable of state ownership in board diversity on dividend payout ratio. OLS regression analysis is used in this study. It aims to explore the effect of board diversity to dividend payout ratio. This research shows that gender, nationality, and tenure diversity is positively related to dividend payments. In addition, this study founds that state ownership positively moderated gender and tenure diversity on dividend payments. However, state ownership is not significant when moderate the effect of nationality diversity on dividend payments.
\end{abstract}

Keywords: Gender diversity, Board of commissioners, Dividend payout ratio, State ownership

\section{Introduction}

The industrial sector is one of the important sectors in national economic development. This is due to the significant contribution of the industrial sector to Indonesia's economic growth. The industry sector is believed to be able to encourage the productivity of a country to be more advanced. Industrial conditions in Indonesia currently show relatively low growth. The chronic industrial downturn should be taken seriously. The decline in the role of the industrial sector is inseparable from the weakening of the supporting factors of industry competitiveness [1]. According to data from The Ministry of Industry Indonesia (2015), the rate of growth in 2014 decreased by $82.50 \%$ [1]. But in 2015, the achievement of the target increased to 84 percent. However, The Ministry of Industry Indonesia (2015) would be a difficult year for domestic industry players [1]. This is due to the slowdown in the world economic growth that has an impact on the domestic economy. During 2015, BPS announced that the growth of the manufacturing industry only grew by 4.57 percent. The increase in manufacturing industrial production during the fourth quarter grew by only 1.6 percent against the third quarter of 2015 . Based on 2014 data, manufacturing contributed the highest contribution to GDP, in addition to the agricultural sector (13.4 percent of GDP) and trade (13 percent of GDP). The largest production growth occurred in the pharmaceutical sub-sector with a production increase of 15.27 percent.

The Ministry of Industry Indonesia noted that more than half of investments, both Foreign Direct Investment (PMA) and Domestic Investment (PMDN) throughout 2016 flowed into the manufacturing sector [1]. The manufacturing sector is still an attraction to invest for foreign and local investors. Based on data from the Indonesian Investment Coordinating Board (BKPM), investor funds amounting to Rp.335.8 trillion were invested in the manufacturing sector or around 54.7 percent of the total investment of Rp.613 trillion in 2016 [2]. Realization of 2016 
investments increased 12.4 percent compared to the 2015 investment value amounting to Rp.545.4 trillion. The total realization of the 2016 investment value reached 103 percent of the targeted value of Rp. 594.8 trillion. The realization of PMDN reached Rp. 216.2 trillion or 103.8 percent of the target of Rp 208.4 trillion. While the realization of FDI reached Rp. 396.6 trillion or 102.7 percent of the pegged Rp 386.4 trillion. Therefore, the government needs to pay attention to the industrial sector so that Indonesia's competitiveness in global economic markets will increase and create a conducive business climate for investors, so that investment performance in Indonesia will increase.

In Indonesia, there are several issuers that routinely pay dividends every year and set a dividend payout ratio every year including, PT Jasa Marga distributes dividends higher than the previous year. PT Jasa Marga's dividends in 2016 amounted to Rp 566.79 billion, or $30 \%$ of the net profit in 2016 of Rp 1.89 trillion [3]. Whereas in 2015, PT Jasa Marga distributed dividends amounting to Rp. 293.27 billion or $20 \%$ of 2015 profit which amounted to Rp. 1.46 trillion profit [4]. Based on the explanation above, it can be said that the proportion of dividends paid to shareholders depends on the company's ability to generate profits and the form of dividend policy applied by the company concerned. Therefore, the proportion of dividends can change every year; this is because the decision to pay dividends also considers the internal conditions and external conditions of the company [5].

One of the factors that can influence dividend policy is the diversity of the board of commissioners in the company. According to Byoun et al., (2016) found that US companies with gender and miniature diversity boards tend to pay dividends more often than firms with non-diverse boards [6]. Hamzah and Zulkafli (2014) stated that there was a positive relationship between the diversity of foreign commissioners and the dividend payout ratio [7]. The study shows that the presence of foreign nationals on the board of commissioners will bring benefits to shareholders because the board will become more independent and monitoring can run well, so the level of expropriation in the company can be reduced. Hamzah and Zulkafli (2014) show that board tenure has a negative relationship with the dividend payout ratio in Malaysian public companies [7].

In addition, state ownership can also influence the board of directors in dividend policy. State-owned firms tend to pay higher dividends to shareholders due to higher agency problems compared to private firms. The agency problem arises because there are two interests in a stateowned firm. First, the conflict between shareholders and management is due to information asymmetry between the two parties. This information asymmetry causes company management to tend to do the moral hazard. The management of the company has an obligation to maximize the welfare of shareholders, but management also has an interest in maximizing one's own wellbeing [8]. Second, the conflict between politicians and citizens of the country which is usually caused by residents feel that state-owned firms work inefficiently and sometimes the government's decision does not get support in the community [8].

Developing countries, such as Indonesia, have sought to adopt the legal framework of developed countries but formal institutions such as laws and regulations regarding accounting requirements, information disclosure, securities trading, and enforcement are inefficient or not operating as intended [9]. Therefore, standard corporate governance mechanisms have relatively little institutional support in developing countries. This result in informal institutions, such as relational ties, business groups, family connections, and government contacts, all playing a greater role in shaping corporate governance [10]. Institutional environments in developing countries are weak and the largest companies are still under family access. Finally, these companies try to separate from access to professional management. However, informal families often control through other means [11]. This strategy can cause the controlling shareholders 
often to do the expropriation of the value from minority shareholders, which refers to the transfer of value from the minority shareholders to the majority or controlling shareholders [12]. So, corporate should have Board of Commissioners $(\mathrm{BoC})$ that can protect the minority shareholder and reduce the expropriation from management or controlling shareholder.

Adams \& Ferreira (2009) show that a board of diverse gender is considered a better management monitor because it is more likely to support the interests of shareholders [13]. In addition, a gender diverse board have greater monitoring than no diverse board, because they have various viewpoints and active oversights in evaluating management decisions [14]. Board gender diversity has a greater predisposition to align the economic incentives of managers and shareholders through its effects on dividend policy [8]. Previous literature shows that gender diverse boards positively related to dividend payout. Byoun et al., (2016) shows similar results for US firms and report that firms with gender diverse boards are more likely to pay dividends than firms with non-diverse boards [6]. Based on above discussion, it can be concluded if gender diversity monitoring in a company is going well, then expropriation will decrease and dividends distributed to shareholders will be higher. Thus, the more gender diversity on the board of commissioners, the higher the dividend payment policy decision will be to shareholders.

\section{H1: Gender diversity positively affects the dividend payouts.}

Denis \& McConnell (2002) define corporate governance as a set of mechanisms, involved in organization's decision-making with the objective to maximize the organization's value and to increase shareholders' wealth [15]. Therefore, every action and decision taken by the company is intended to provide benefits to all shareholders of the company. Corporate governance deals with the ways in which supplier of finance are assured of getting a return on their investments. This view is more specific in explaining the possibility of expropriation and the role of board of directors in protecting the shareholders' interest. This is brought up by Claessens et al., (2000) with the argument that corporate governance is related to the role of multiple shareholders and board of commissioners (BoC) [16].

Nationality diversity on $\mathrm{BoC}$ will make a better decision and strategy for the company and will increase the monitoring to avoid the expropriation by management of the company. When the monitoring is success, the expropriation will reduce in company. The presence of foreign board improved firm's performance due to monitoring function carried out by them and making the board to be more independence by reducing the expropriation and restrict the power of existing board members (Choi et al., 2007) and foreign board bring diverse opinion and views, professional experiences and different thinking, and heterogeneity $[17,18]$. On another hand, the local commissioner will increase monitoring and knowledge about local business environment [19]. Nationality diversity will make the board more active and efficient because of the transfer knowledge on the board. Based on above discussion, it can be concluded if nationality diversity monitoring in a company is going well, then expropriation will decrease and dividends distributed to shareholders will be higher. Thus, the more nationality diversity on the board of commissioners, the higher the dividend payment policy decision will be to shareholders.

\section{H2: Nationality diversity positively affects the dividend payouts.}


Board tenure is an additional determinant of commissioner quality. There are conflicting views regarding the effect of commissioner tenure on commissioner behaviour. Vance (1983) argues that forcing directors to retire leads to a waste of talent and experience [20]. Similarly, Buchanan (1974) finds that extended tenure enhances organizational commitment and willingness to expend effort toward company goals [21]. Long board tenure makes the board members more mature and will influence decision making. With their vast experience, they are better directing policies of the firm [22,23]. It also enhances of the effectiveness of the monitoring especially on financial reporting [11]. In addition, commissioners tenure is determinant of commissioners quality [23]. But, The National Association of Corporate Directors (1996) suggests a maximum of 10 to 15 years of board service in order to obtain the fresh ideas and critical thinking for management. Similarly, Hamzah and Zulkafli (2014) find that longer board tenure is associated with a lower dividend which may translated into a higher corporate expropriation [7]. This may be an indication that board members with longer tenure and maturity have some influence that possibly leads to more expropriations due to the strong relationship with the management. This makes their monitoring role to be less effective. It also consistent with the previous results, long tenure directors seem to have close relationship with the management which leads to a reduction in the monitoring effect and to have an effect on decision making in the firm [23].

Therefore, the company needs to have a right composition for the tenure of BoC. It aims that the board of commissioners can be critical in providing appropriate advice for the management of the company and conducting good supervision [23]. When monitoring in family firms goes well, the expropriation at the firms will decrease. Expropriation is the process of using controls to maximize the insider welfare of a company. There are several policies that can lead to expropriation such as a declining dividend policy that is not even distributed. So, it can be concluded if monitoring in a company is going well, then expropriation will decrease and dividends distributed to shareholders will be higher. Based on above discussion, it can be concluded if tenure diversity monitoring in a company is going well, then expropriation will decrease and dividends distributed to shareholders will be higher. Thus, the more tenure diversity on the board of commissioners, the higher the dividend payment policy decision will be to shareholders.

\section{H3: Tenure diversity positively affects the dividend payouts.}

According to Saeed and Sameer (2017), state-owned firms tend to have high agency problems compared to private firms [8]. Agency issues at the state-owned firms in developing countries tend to be higher [25,26]. Gugler (2003) argues that state-owned firms tend to have high agency problems [27]. Although citizens are the main owners, they do not have direct control over these firms because there is already a management company appointed by the government. Management is usually inefficient in running a company, causing conflict between the government and the citizen. So, to ensure that the company is running well, companies owned by the government tend to build a good reputation in investors.

Some research shows that state ownership are usually not so difficult to finance investment projects, but the government as a strong investor must protect shareholders by paying high dividends. High dividend payments will build a good reputation on the stock exchange, and the government also does not want to have problems with shareholders related to the image of the company that is considered important in the capital market so that the ability to pay dividends is also increasing [28]. Then, La Porta et al., (2000) and Bae et al., (2012) show that companies with good governance use high dividend payments to reduce agency conflicts [12, 29]. 
Gender diversity in state-owned firms is also expected to give a signal to the general public about managerial effectiveness and good governance [30]. One of the positive signals is by paying high dividends to shareholders. Investors believe that companies that make high dividend payments show the company has been convinced that future cash flows will be large enough to bear high dividends [31]. Thus, the more gender diversity on the board of commissioners are moderated by state ownership, the higher the dividend payment policy decision to shareholders.

\section{H4: The positive influence the gender diversity on dividend payout ratio is stronger in firms that have state-ownership.}

State ownership companies have some features compared to other private companies in developing countries such as privileges in credit loans when government-owned companies are experiencing financial distress [32]. The specialty is that the banking industry in emerging markets can still be controlled by the government [33]. Therefore, state-owned firms have a close relationship with state-owned banks and have special treatment in the credit market. This preferential treatment will increase cash flow which can encourage managers to take over and carry out selfish actions. Kikeri et al., (1992) show that state-owned firms generally tend to be inefficient, because these companies tend to pursue political goals and the losses of state-owned firms can lead to massive economic deficiencies [34]. Gugler (2003) argues that state-owned firms tend to have high agency problems. Although citizens are the main owners, they do not have direct control over these companies because there has been management appointed by the government [27]. Management is usually inefficient in running company operations. Therefore, shareholders increase supervision of government-owned companies [8]. One way to improve company monitoring by providing the right citizenship for each commissioner. The presence of national commissioners will enhance the company's good corporate governance and improve the company's performance [19].

The diversity of the board of commissioners diversity can also improve investor supervision. The presence of foreign investors in the company will become owners of capital that will uphold commissioners who are also foreign nationals [17]. Through commissioners, investors can supervise and ensure they are protected [35]. Gulamhussen and Guerreiro (2009) show that nationality board members can be used to help improve the efficiency and operational efficiency of a company to incur substantial costs for them [36]. On another hand, local commissioner will increase monitoring and knowledge about local business environment [19]. However, the local commissioners are needed in the company management unit so that the shareholders are not harmed. Nationality diversity will make the board more active and efficient because of the transfer knowledge on the board. Thus, the more nationality diversity on the board of commissioners are moderated by state ownership, the higher the dividend payment policy decision to shareholders.

\section{H5: The positive influence the nationality diversity on dividend payout ratio is stronger in firms that have state-ownership.}

According to Büge et al., (2013), state-owned firms have several features compared to other private companies in developing countries such as privileges in credit loans when government ownership is experiencing financial distress [32]. The specialty is that the banking industry in emerging markets can still be controlled by the state [33]. Therefore, state-ownership has a close relationship with state-owned banks and has special treatment in the credit market. This 
preferential treatment will increase cash flow which can encourage managers to take over and carry out selfish actions.

State-ownership generally tends to be inefficient because of the political objectives carried out by the government. Losses of state-owned companies can also lead to massive economic deficiencies [34]. Gugler (2003) argues that state-owned firms tend to have high agency problems. Although citizens are the main owners, they do not have direct control over these companies because there has been management appointed by the government [27]. Management is usually inefficient in running the company's operations, causing conflicts between the government and the community. Therefore, shareholders tend to increase supervision of government ownership companies [8]. One way to improve company monitoring is by having the right composition of tenure on the board of directors to cover each other's shortcomings in the commissioner.

Buchanan (1974) finds that a long tenure would increase the commitment of commissioners in achieving company goals. Hamzah and Zulkafli (2014) argue that commissioners who have a long tenure make commissioners can increase the effectiveness of monitoring within the company [7]. The National Association of Corporate Directors (1996) argues that changing business conditions quickly also requires changes in the composition of the board. The Commission recommends that the maximum tenure for commissioners is 10 to 15 years. This is so that the board of commissioners can provide fresh ideas and critical thinking to the company's management. Therefore, the company needs to have a composition of the diversity of the board of commissioners by considering the right term of office so that the board of commissioners is critical in providing appropriate advice for the management of the company and carrying out good supervision [23]. Good supervision will prevent company insiders from carrying out expropriation actions such as high salaries and benefits, large bonuses and compensation, high pension funds, and reduced or not divided dividends. If, expropriation is reduced, the company will pay high dividends to shareholders Thus, the more tenure diversity on the board of commissioners are moderated by state ownership, the higher the dividend payment policy decision to shareholders.

H6: The positive influence the tenure diversity on dividend payout ratio is stronger in firms that have state-ownership.

\section{Method}

This study used a sample of non financial firms on Indonesia Stock Exchange and consistently published financial statements in Rupiah during period 2014-2016. The sample used in the study included 532 companies for variable gender diversity. The research sample for nationality diversity variable was 697 sample companies. The tenure diversity has a sample of 691 sample companies. We used OLS regression and sixth models in this paper.

\subsection{Dependent variable}


In this study, dividend payout ratio is primarily measured by the ratio of the dividend per share to net income per share. The data variable is directly computed from balance sheet of the company.

\subsection{Independent variable}

Gender diversity: The board gender diversity (GENCOM) is defined as the number of woman directors on the board divided by the number of all board members.

Nationality diversity: To measure foreign board (NATCOM), this study used to the number of foreign commissioners who sit on the board divided by the number of all board members.

Tenure diversity: The tenure of commissioners (TENCOM) is measured by the percentage of commissioners whose tenure is equal or greater than to 8 years divided by the number of all board members.

\subsection{Moderation variable}

State Ownership :To measure state ownership (STOSHIP), this study used to the fraction of common shares held by government.

\subsection{Control variable}

Firm Size: In this study, we control for firm size; firm size is measured by the natural log of a firm's total assets. Previous literature shows that a significant positive impact of firm size on dividend payments.

Board Size: The second control variable is board size, board size is measured as the natural logarithm of the number of commissioners.

\subsection{Model specification}

The regression model will be used to test all hypotheses in the sample period during 20142016. The models specification to test our hypotheses is as follows :

Model 1:

To find out the effect of gender diversity on dividend payout ratio with firm size and board size control variables, it is necessary to build a regression equation model as follows:

$$
D I V_{i t}=\beta_{0}+\beta_{1} \text { GENCOM }_{i t}+\beta_{2} \text { FIRSIZ }_{i t}+\beta_{3} \text { BOASIZ }_{i t}+\varepsilon_{i t}
$$

Model 2 :

To find out the effect of nationality diversity on dividend payout ratio with firm size and board size control variables, it is necessary to build a regression equation model as follows:

$$
D_{\text {IV }}=\beta_{0}+\beta_{1} \text { NATCOM }_{i t}+\beta_{2} \text { FIRSIZ }_{i t}+\beta_{3} \text { BOASIZ }_{i t}+\varepsilon_{i t}
$$

Model 3 :

To find out the effect of tenure diversity on dividend payout ratio with firm size and board size control variables, it is necessary to build a regression equation model as follows: 


$$
D I V_{i t}=\beta_{0}+\beta_{1} \text { TENCOM }_{i t}+\beta_{2} \text { FIRSIZ }_{i t}+\beta_{3} \text { BOASIZ }_{i t}+\varepsilon_{i t}
$$

Model 4 :

To determine the effect of gender diversity on dividend payout ratio which is moderated by state-ownership and with the firm size and board size control variables, it is necessary to build a regression equation model as follows:

$$
\begin{gathered}
D I V_{i t}=\beta_{0}+\beta_{1} G_{E N C O M}+\beta_{2} \text { GENCOM }_{i t} * \operatorname{STOSHIP}_{i t}++\beta_{3} \text { FIRSIZ }_{i t}+\beta_{4} \text { BOASIZ }_{i t} \\
+\varepsilon_{i t}
\end{gathered}
$$

Model 5 :

To determine the effect of nationality diversity on dividend payout ratio which is moderated by state-ownership and with the firm size and board size control variables, it is necessary to build a regression equation model as follows:

$$
\begin{gathered}
D I V_{i t}=\beta_{0}+\beta_{1} N_{A T C O M}+\beta_{2} \text { NATCOM }_{i t} * \operatorname{STOSHIP}_{i t}++\beta_{3} \text { FIRSIZ }_{i t}+\beta_{4} \text { BOASIZ }_{i t} \\
+\varepsilon_{i t}
\end{gathered}
$$

Model 6 :

To determine the effect of tenure diversity on dividend payout ratio which is moderated by stateownership and with the firm size and board size control variables, it is necessary to build a regression equation model as follows:

$$
\begin{gathered}
D I V_{i t}=\beta_{0}+\beta_{1} \text { TENCOM }_{i t}+\beta_{2} \text { TENCOM }_{i t} * \operatorname{STOSHIP}_{i t}++\beta_{3} \text { FIRSIZ }_{i t}+\beta_{4} \text { BOASIZ }_{i t} \\
+\varepsilon_{i t}
\end{gathered}
$$

Where :

$\begin{array}{ll}\text { DIV } & =\text { Dividend Payout Ratio } \\ \text { GENCOM } & =\text { Gender Commissioners } \\ \text { NATCOM } & =\text { Nationality Commissioners } \\ \text { TENCOM } & =\text { Tenure Commissioners } \\ \text { STOSHIP } & =\text { State Ownership }\end{array}$

FIRSIZ = Firm Size

BOASIZ = Board Size

$\varepsilon \quad=$ Error

\section{Results}


The descriptive statistics for gender diversity is presented in table 1. It includes observation from 527 non-financial firms in Indonesia. The mean and maximum of absolute value of dividend payout ratio are $5,93 \%$ and $49,2 \%$. In term of gender, even though there are companies without woman commissioners, there are companies which are having a maximum of 0,5 women sit in the board of commissioners in non financial firms in Indonesia. At the same time, the average proportion of gender diversity in the board of commissioners in state ownership is $0,42 \%$. There are state ownership that do not have gender diversity on boards of commissioners and state ownerships tend to be filled by men on the board of commissioners because the highest proportion of female commissioners in state ownership on the board of commissioners is only $27 \%$ of the total of all commissioners.

Table 1. Descriptive Statistics for Variable Regression Model.

\begin{tabular}{llllll}
\hline Gender & $\mathrm{N}$ & Min & Max & Mean & Std Dev \\
\hline DIV & 532 & 0.0000 & 0.4920 & 0.0587 & 0.1106 \\
GENCOM & 532 & 0.0000 & 0.5000 & 0.1590 & 0.1675 \\
GENCOMXSTOSHIP & 532 & 0.0000 & 0.2700 & 0.0042 & 0.0297 \\
FIRSIZ & 532 & 18.715 & 38.656 & 28.201 & 2.2531 \\
BOASIZ & 532 & 0.6931 & 2.8904 & 1.3339 & 0.4154 \\
Nationality & $\mathrm{N}$ & Min & Max & Mean & Std Dev \\
DIV & 697 & 0.0000 & 0.9990 & 0.1500 & 0.2068 \\
NATCOM & 697 & 0.0000 & 0.5000 & 0.0538 & 0.1223 \\
NATCOMXSTOSHIP & 697 & 0.0000 & 0.3600 & 0.0016 & 0.0205 \\
FIRSIZ & 697 & 18.715 & 38.656 & 28.459 & 2.0023 \\
BOASIZ & 697 & 0.6931 & 3.0910 & 1.3474 & 0.4113 \\
Tenure & $\mathrm{N}$ & Min & Max & Mean & Std Dev \\
DIV & 691 & 0.0000 & 0.9990 & 0.1420 & 0.2229 \\
TENCOM & 691 & 0.0000 & 0.5000 & 0.1400 & 0.1788 \\
TENCOMXSTOSHIP & 691 & 0.0000 & 0.3600 & 0.0027 & 0.0267 \\
FIRSIZ & 691 & 18.715 & 38.656 & 28.401 & 2.0363 \\
BOASIZ & 691 & 0.6931 & 2.4849 & 1.3499 & 0.4114 \\
\hline
\end{tabular}

The descriptive statistics for nationality diversity is presented in table 1. It includes observation from 697 non-financial firms in Indonesia. The mean and maximum of absolute value of dividend payout ratio are $15 \%$ and $99.9 \%$. There are companies without foreign commissioners, there are companies which are having a half of commissioners foreigners sit in the board of commissioners in non financial firms in Indonesia. Regarding ownership structure, the average proportion of nationality diversity in the board of commissioners in state ownership is $0.16 \%$. There are state ownerships that do not have gender diversity on boards of commissioners and state ownership tend to be filled by men on the board of commissioners because the highest proportion of foreign commissioners in state ownership on the board of commissioners is only $36 \%$ of the total of all commissioners.

The descriptive statistics for tenure diversity is presented in table 1. It includes observation from 691 non-financial firms in Indonesia. The mean and maximum of absolute value of dividend payout ratio are $14.20 \%$ and $99.90 \%$. There are companies without any commissioners with tenure of at least of 8 years while there are also companies with half of commissioners serving the board for a minimum period of 8 years. Regarding ownership structure, the average proportion of tenure diversity in the board of commissioners in state ownership is $0.27 \%$. There are state ownerships that do not have gender diversity on boards of commissioners and state 
ownership's tended to be filled by men on the board of commissioners because the highest proportion of foreign commissioners in state ownership on the board of commissioners is only $36 \%$ of the total of all commissioners.

\section{Discussion}

Table 2. The Result of Gender Regression Model

\begin{tabular}{lc}
\hline Variable & Coefficient \\
\hline Constant & $-0.301 * *$ \\
& $(0.000)$ \\
GENCOM & $0.092^{* *}$ \\
& $(0.001)$ \\
FIRSIZ & $0.009 * *$ \\
& $(0.000)$ \\
BOASIZ & $0.063 * *$ \\
& $(0.000)$ \\
R-squared & 0.141 \\
Adjusted R-square & 0.136 \\
\hline **Significant at 5\% level &
\end{tabular}

Table 2 presents the result of the gender diversity variable of the board of commissioners has a significant positive effect on the dividend payout ratio. This means that companies that have gender diversity on the right board of commissioners have higher dividend payments to shareholders. This result is consistent with stakeholder theory; gender diversity on the board of commissioners will help in understanding the expectations of stakeholders [37]. The financial behaviour literature suggests that corporate dividend payment decisions need to take into account the level of investor patience that varies between cultures [38]. In developing countries that have high economic uncertainties such as Indonesia, shareholders tend to be impatient in their return on investment, so they will ask for a high dividend payment to the company. The nature of women tends to have a higher level of sensitivity than men, so women commissioners are required to better understand the demands of shareholders [39]. Female commissioners in developing countries can assist in overcoming claims of investors who are impatient by choosing a high dividend payment policy.

Table 3. The Result of Nationality Regression Model

\begin{tabular}{lc}
\hline Variable & Coefficient \\
\hline Constant & $-0.597 * *$ \\
& $(0.000)$ \\
FORCOM & $0.251^{* *}$ \\
& $(0.000)$ \\
FIRSIZ & $0.023^{* *}$ \\
& $(0.000)$ \\
BOASIZ & $0.060^{* *}$ \\
& $(0.007)$ \\
R-squared & 0.136 \\
Adjusted R-square & 0.132 \\
\hline
\end{tabular}

**Significant at 5\% level 
Table 3 shows the nationality diversity is positively related to dividend payout ratio. The variable nationality diversity of the board of commissioners has a significant positive effect on the dividend payout ratio. This means that firms have the right diversity of nationality on the board of commissioners have higher dividend payments to shareholders than non-nationality diverse board. Diversity of nationality is believed to make the company have better decisions and strategies and increase supervision in preventing expropriation actions taken by company management. Board of commissioners with foreign nationalities are believed to be able to improve the performance of the company because it brings a variety of opinions and views, professional experience and different thoughts [18]. The diversity of the board of commissioners' nationality can also improve supervision in protecting foreign investors.

However, Masulis et al., (2012) show that foreign commissioners would bring poor performance and a poor level of supervision to the company due to ignorance of the local business environment [19]. Thus, local commissioners are required to oversee the company's management board so that shareholders are not harmed. Therefore, companies need to have the right composition of the authority of the board of commissioners to cover their respective shortcomings in the commissioners. One of the ways to improve the monitoring of a company by having the composition of the diversity of authority of the board of directors is the right to cover the shortcomings of each of the commissioners. The presence of foreign and local commissioners aims to bring competitive advantage to the company, improve the company's good corporate governance, and improve the company's performance $[7,19]$. When monitoring the company goes well, the expropriation at the company will decrease. There are several policies that can lead to expropriation such as a declining dividend policy that is not even distributed. So, if monitoring in a company goes well, then expropriation will decrease and dividends distributed to shareholders will be higher. In addition, we find a positive and significant coefficient for control variables. First, firm size is positively relationship with dividend payout ratio. It indicates that larger firms are more likely to distribute dividends [8]. Secondly, we find that the dividend payments increases with the increase of corporate board size. This result is consistent with Saeed and Sameer (2017) [8].

Table 4. The Result of Tenure Regression Model

\begin{tabular}{lc}
\hline Variable & Coefficient \\
\hline Constant & $-0.443^{* *}$ \\
& $(0.000)$ \\
TENCOM & 0.123 \\
& $(0.008)^{* *}$ \\
FIRSIZ & $0.017 * *$ \\
& $(0.001)$ \\
BOASIZ & $0.068^{* *}$ \\
& $(0.006)$ \\
R-squared & 0.075 \\
Adjusted R-square & 0.071
\end{tabular}

**Significant at $5 \%$ level

Based on the results of multiple linear regression tests using SPSS that has been done, table 4 shows that the variable tenure diversity of the board of directors has a significant positive effect on the dividend payout ratio. This means that firms that have the right diversity of tenure on the board of commissioners have higher dividend payments to shareholders than non- 
diversity firms board. The diversity of tenure on the board of commissioners will make the board of commissioners critical in providing appropriate advice for the management of the company and conducting good supervision [23].

The long tenure will make the commissioner more mature in deciding company policy. This is because the commissioners have had a lot of experience, commitment, and competence so that the commissioners understand the condition of the company and its business environment. Vance (1983) argues that forcing commissioners to retire will cause waste of talent and experience [20]. Buchanan (1974) found that the long tenure would increase the commitment of the commissioner in achieving the company's goals. However, a long tenure also had a negative impact on the company [21]. The business community has raised concerns about commissioners who have been on the board of commissioners for too long, potentially harming shareholders. The National Association of Corporate Directors/NACD (1996) argues that changing business conditions quickly also requires changes in the composition of the board. NACD recommends that the maximum term of office for commissioners is 10 to 15 years. This is so that the board of commissioners can provide fresh ideas and critical thinking to the company's management. When monitoring the company goes well, the expropriation at the company will decrease. Expropriation is the process of using controls to maximize the insider welfare of a company. There are several policies that can lead to expropriation such as a declining dividend policy that is not even distributed. So, it can be concluded if monitoring in a company is going well, then expropriation will decrease and dividends distributed to shareholders will be higher.

Table 5. The Result of Gender \& Moderation Regression Model

\begin{tabular}{lc}
\hline Variable & Coefficient \\
\hline Constant & $-0.295^{* *}$ \\
& $(0.000)$ \\
GENCOM & $0.085^{* *}$ \\
& $(0.002)$ \\
GENXSTOSHIP & $0.388^{* *}$ \\
& $(0.010)$ \\
FIRSIZ & $0.009^{* *}$ \\
& $(0.000)$ \\
BOASIZ & $0.062^{* *}$ \\
& $(0.000)$ \\
R-squared & 0.151 \\
Adjusted R-square & 0.145 \\
\hline **Significant at 5\% level &
\end{tabular}

Table 5 presents that state-ownership positively moderates the relationship between gender diversity and dividend payout ratio. This means that the positive influence of the Board of Commissioners (BoC) gender diversity on the dividend payout ratio becomes stronger in government ownership companies. Gugler (2003) argues that state-owned companies tend to have high agency problems [27]. Agency problems in state-owned companies occur because of different political and public interests. Basically, state ownership of a company is technically controlled by public, but carried out by bureaucrats who can have concentrated control rights but do not have cash flow rights so that the bureaucrats have conflicts over increasing social welfare and controlled by political interests [40]. Thus, citizens tend to feel that they own and supervise state owned-firms but do not have direct control over these companies because there 
is already a management company appointed by the government. Management is usually inefficient in running a company, causing conflict between the government and the citizens. Therefore, companies usually take actions that prove that the company is running well and build a good reputation in investors.

High dividend payments are one way to build a good reputation on the stock exchange. La Porta et al., (2000) and Bae et al (2012) show that firms with good governance use high dividend payments to reduce agency conflicts $[12,29]$. Gender diversity in state-owned firms is also believed to provide a signal to the general public regarding managerial effectiveness and good governance [30]. The corporate governance literature shows that gender diversity on the board of commissioners can influence supervision and control in management activities [13]. Therefore, state-owned firms strengthen the gender diversity of the board of commissioners in increasing the dividend payout ratio.

Table 6 presents that the moderating role of state-ownership does not remain significant between nationality diversity and dividend payout ratio. This means that the influence of the board of Commissioners' diversity in dividend payout ratio becomes weaker for companies that have state ownership. Companies that have a diversity of nationalities on the board of commissioners have a less effective level of supervision due to several reasons.

Table 6. The Result of Nationality with Moderation Regression Model

\begin{tabular}{lc}
\hline Variable & Coefficient \\
\hline Constant & $-0.596^{* *}$ \\
& $(0.000)$ \\
FORCOM & $0.265^{* *}$ \\
& $(0.000)$ \\
FORCOMXSTOSHIP & -0.366 \\
FIRSIZ & $(0.317)$ \\
& $0.023^{* *}$ \\
BOASIZ & $(0.000)$ \\
& $0.060^{* *}$ \\
R-squared & $(0.007)$ \\
Adjusted R-square & 0.137 \\
**Significant at 5\% level & 0.132
\end{tabular}

First, the presence of foreign commissioners on the board of commissioners will reduce the level of supervision on management; this is because foreign commissioners tend to have less access to current information about current operations and company performance. Second, foreign-state commissioners tend to be less familiar with the conditions of the country the company is running, such as accounting rules, laws and regulations, governance standards and management methods that will make foreign commissioners more difficult to evaluate managerial performance or challenge managerial decisions [41]. This limitation will interfere with the work of the entire board of commissioners in supervising company management. Another reason why government ownership variables do not have a significant effect in strengthening the positive influence of the board's diversity of citizenship on the dividend payout ratio is that researchers rarely find foreign commissioners who sit on the board of stateowned firms in Indonesia.

Based on the results of multiple linear regression tests using SPSS that have been done, government ownership variables significantly strengthen the positive influence of the diversity 
of the term of the board of commissioners on the dividend payout ratio. This means that the positive influence of the diversity of tenure of the board of commissioners on the dividend payout ratio becomes stronger in government ownership companies.

Table 7. The Result of Tenure with Moderation Regression Model

\begin{tabular}{lc}
\hline Variable & Coefficient \\
\hline Constant & -0.436 \\
& $(0.000)$ \\
TENCOM & 0.111 \\
TENCOMXSTOSHIP & $(0.017)$ \\
& 0.604 \\
FIRSIZ & $0.050)$ \\
& 0.017 \\
BOASIZ & $0.001)$ \\
& 0.057 \\
R-squared & $0.007)$ \\
Adjusted R-square & 0.081 \\
\hline$* *$ Significant at 5\% level & 0.075
\end{tabular}

Table 7 presents that state-ownership positively moderates the relationship between tenure diversity and dividend payout ratio. The positive influence of the diversity of tenure of the board of commissioners on the dividend payout ratio becomes stronger in state ownership companies. State ownership generally tends to be inefficient because of the political objectives carried out by the government. Losses of state-owned companies can also lead to massive economic deficiencies [34]. Gugler (2003) argues that state-owned companies tend to have high agency problems [27]. Although citizens are the main owners, they do not have direct control over these companies because there has been management appointed by the government. Management is usually inefficient in running the company's operations, causing conflicts between the government and the citizens. Therefore, shareholders tend to increase supervision of government ownership companies [8].

Buchanan (1974) found that a long term of office would increase the commitment of commissioners in achieving company goals [21]. Hamzah and Zulkafli (2014) argue that commissioners who have a long tenure make commissioners can increase the effectiveness of monitoring within the company [7]. The National Association of Corporate Directors/NACD (1996) argues that changing business conditions quickly also requires changes in the composition of the board. The Commission recommends that the maximum term of office for commissioners is 10 to 15 years. This is so that the board of commissioners can provide fresh ideas and critical thinking to the company's management. Therefore, the company needs to have a composition of the diversity of the board of commissioners by considering the right term of office so that the board of commissioners is critical in providing appropriate advice for the management of the company and carrying out good supervision [23].

Good supervision will prevent company insiders from carrying out expropriation actions such as high salaries and benefits, large bonuses and compensation, high pension funds, and reduced or not divided dividends. If, expropriation is reduced, the company will pay high dividends to shareholders. 


\section{Conclusion}

The purpose of this study are (1) to examine the effect of board diversity on dividend payout ratio, and (2) to determine the effect state ownership variables on theboard diversity relationship to dividend payout ratio. After doing the analysis by using OLS method to determine the effect between variables, the results of the research arethe diversity gender that are differentiated by gender, nationality, and tenure on board of commissioners have a significant positive effect on dividend payouts ratio. It means the board that have right and balanced composition for board of commissioner, the higher dividend payout ratio of the firm. State ownership as a moderating variable shows different results in the relationship between board diversity on dividend payout ratio. State ownership strengthens the positive influence of gender diversity and tenure diversity on dividend payout ratio. Meanwhile, the moderating role of state ownership does not remain significant between nationality diversity on dividend payout ratio.

The contribution that can be given by this research is firstly, this research contribute knowledge about the right and balance composition for board diversity will be influence the board of commissioners. Second, the diversity of the board of commissioners will have an influence in influencing the company's dividend policy. Thus, it has implications for shareholders in the form of the need to pay attention to the composition of gender, nationality and tenure on the board of commissioners so that dividends distributed to shareholders can be higher and the interests of shareholders can be protected by the board of commissioners. The author suggests future research should include about age or education of board of commissioners to dividend payout ratio.

\section{References}

[1] Kementrian Perindustrian: "Laporan Tahunan Kementrian Perindustrian,” (2015).

[2] Indonesian Investment Coordinating Board: "Indonesian Investment Coordinating Board.".

[3] Jasa Marga: "Jasa Marga Annual Report," (2017).

[4] JasaMarga: "Annual Report JasaMarga 2016 - Akselerasi Pembangunan Infrastruktur," (2016).

[5] Sudana, I. M.Manajemen Keuangan Perusahaan Teori dan Praktik. Jakarta: Erlangga, 2011(2011).

[6] Byoun, S.Chang, K.and Kim, Y. S.: "Does Corporate Board Diversity Affect Corporate Payout Policy?," Asia-Pacific J. Financ. Stud., vol. 45, no. 1, pp. 48-101, (2016), doi: 10.1111/ajfs.12119.

[7] Hamzah, A. H. and Zulkafli, A. H.: "Board Diversity and Corporate Expropriation," Procedia - Soc. Behav. Sci., vol. 164, no. September, pp. 562-568, (2014), doi: 10.1016/j.sbspro.2014.11.146.

[8] Saeed, A. and Sameer, M.: "Impact of board gender diversity on dividend payments: Evidence from some emerging economies," Int. Bus. Rev., vol. 26, no. 6, pp. 11001113, (2017), doi: 10.1016/j.ibusrev.2017.04.005.

[9] Young, M. N.Peng, M. W.Ahlstrom, D.Bruton, G. D.and Jiang, Y.: "Corporate governance in emerging economies: A review of the principal-principal perspective: Review paper," J. Manag. Stud., vol. 45, no. 1, pp. 196-220, (2008), doi: 10.1111/j.1467-6486.2007.00752.x. 
[10] Yeung, H. W. C.: "Change and Continuity in Southeast Asian Ethnic Chinese Business," pp. 229-254, (2006), doi: 10.1007/s10490-006-9007-2.

[11] Liu, G.Sun, J.and Sun, J.: "Director tenure and independent audit committee effectiveness Director Tenure and Independent Audit Committee," (2010).

[12] Porta, R. LaLopez-de-silanes, F.Shleifer, A.and Vishny, R.: "Investor protection and corporate governance," vol. 58, pp. 3-27, (2000).

[13] Adams, R. B. and Ferreira, D.: "Women in the boardroom and their impact on governance and performance," J. financ. econ., vol. 94, no. 2, pp. 291-309, (2009), doi: 10.1016/j.jfineco.2008.10.007.

[14] Chen, G.Crossland, C.and Huang, S.: "Female board representation and corporate acquisition intensity," Strateg. Manag. J., vol. 37, no. 2, pp. 303-313, (2016), doi: 10.1002/smj.2323.

[15] Denis, D. K. and McConnell, J. J.: "International Corporate Governance," Ssrn, vol. 38, no. 1, pp. 1-36, (2002), doi: 10.2139/ssrn.320121.

[16] Claessens, S.Djankov, S.and Lang, L. H. P.Claessens et al. - 2000 - East Asian Corporations \&.pdf, vol. 58. 2000(2000).

[17] Choi, J. J.Park, S. W.and Yoo, S. S.: "The Value of Outside Directors: Evidence from Corporate Governance Reform in Korea," J. Financ. Quant. Anal., vol. 42, no. 04, p. 941, (2007), doi: 10.1017/S0022109000003458.

[18] Ararat, M., Aksu, M., \& Cetin, A. T.: “The Impact of Board Diversity on Boards' Monitoring Intensity and Firm Performance: Evidence from the Istanbul Stock Exchange," vol. 90, no. 216, (2010).

[19] Masulis, R. W.Wang, C.and Xie, F.: "Globalizing the boardroom-The effects of foreign directors on corporate governance and firm performance," J. Account. Econ., vol. 53, no. 3, pp. 527-554, (2012), doi: 10.1016/j.jacceco.2011.12.003.

[20] VanceCorporate Leadership: Boards, Directors, and Strategy. New York: McGraw Hill, 1983(1983).

[21] Buchanan, B.: "Building Organizational Commitment: The Socialization of Managers in Work Organizations," Adm. Sci. Q., vol. 19, no. 4, p. 533, (1974), doi: $10.2307 / 2391809$.

[22] Liew, C.Y., Samad, M., Munir, S., \& Alfan, E.: "Electronic," (2011).

[23] Vafeas, N.: "Length of board tenure and outside director independence," J. Bus. Financ. Account., vol. 30, no. 7-8, pp. 1043-1064, (2003), doi: 10.1111/1468-5957.05525.

[24] Directors, N. A. of C.: "Report of the NACD Blue Ribbon Commission on Director Professionalism," (1996).

[25] Ben-Nasr, H.: "Government Ownership and Dividend Policy: Evidence from Newly Privatised Firms," J. Bus. Financ. Account., vol. 42, no. 5-6, pp. 665-704, (2015), doi: 10.1111/jbfa.12115.

[26] Bradford, W.Chen, C.and Zhu, S.: "Cash dividend policy, corporate pyramids, and ownership structure: Evidence from China," Int. Rev. Econ. Financ., vol. 27, pp. 445464, (2013), doi: 10.1016/j.iref.2013.01.003

[27] Gugler, K.: "Corporate governance, dividend payout policy, and the interrelation between dividends, R\&D, and capital investment," J. Bank. Financ., vol. 27, no. 7, pp. 1297-1321, (2003), doi: 10.1016/S0378-4266(02)00258-3.

[28] Al Kuwari, D.: "Determinants of the dividend policy of companies listed on emerging stock exchanges: the case of the Gulf Cooperation Council (GCC) countries," Glob. Econ. Financ. J., vol. Vol. 2, No, (2009).

[29] Bae, S. C.Chang, K.and Kang, E.Culture, corporate governance, and dividend policy: 
International evidence, vol. 35, no. 2. 2012(2012).

[30] Saeed, A.Belghitar, Y.and Yousaf, A.: "Firm-level determinants of gender diversity in the boardrooms : Evidence from some emerging markets," Int. Bus. Rev., vol. 25, no. 5, pp. 1076-1088, (2016), doi: 10.1016/j.ibusrev.2016.01.002.

[31] Copeland, WestonFinancial Theory and Corporate Policy, vol. 5, no. 2. 1981(1981).

[32] Büge et al.: "State-owned enterprises in the global economy: Reason for concern?," VOX, 2013. .

[33] Pan, X.Tian, G. G.and Cao, J.: "State Owned vs. Privately Owned Firms: Whose CEOs are Better Compensated?," SSRN eLibrary, (2009).

[34] Kikeri et al: "Privatization: The Lessons of Experience, Washington DC, World Bank." 1992.

[35] Swartz, N. and Firer, S.: "Board structure and intellectual capital performance in South Africa," Meditari Account. Res., vol. 13, no. 2, pp. 145-166, (2005), doi: 10.1108/10222529200500017.

[36] Gulamhussen, M. A. and Guerreiro, L.: "The influence of foreign equity and board membership on corporate strategy and internal cost management in Portuguese banks," Manag. Account. Res., vol. 20, no. 1, pp. 6-17, (2009), doi: 10.1016/j.mar.2008.10.006.

[37] Hillman, A. J.Shropshire, C.Jr, A. A. C.Hillman, A. M. Y. J.and Shropshire, C.: "Organisational Predicators of Women on Corporate Boards," Acad. Manag., vol. 50, no. 4, pp. 941-952, (2007), doi: 10.5465/AMJ.2007.26279222.

[38] Breuer, W.Rieger, M. O.and Soypak, K. C.: "the Behavioral Foundations of Corporate Dividend Policy a Cross Country 2014,” vol. 42, pp. 247-265, (2014).

[39] Galbreath, J.: "Is Board Gender Diversity Linked to Financial Performance? The Mediating Mechanism of CSR,” Bus. Soc., vol. 57, no. 5, pp. 863-889, (2018), doi: $10.1177 / 0007650316647967$.

[40] Mamatzakis, E.Zhang, X.and Wang, C.: "How the corporate governance mechanisms affect bank risk taking," Munich Pers. RePEc Arch., no. 78137, (2017), doi: 10.1227/01.NEU.0000349921.14519.2A.

[41] Coval, J. D. and Moskowitz, T. J.: "The geography of investment: Informed trading and asset prices," J. Polit. Econ., vol. 109, no. 4, pp. 811-841, (2001). 